\title{
Maintaining the Quality of Kacang Buck Semen in Chilled Storage with the Addition of Green Tea Extract in Extender
}

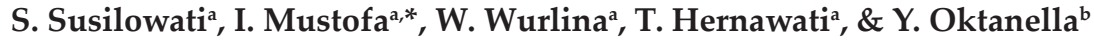 \\ ${ }^{a}$ Division of Veterinary Reproduction, Faculty of Veterinary Medicine, Universitas Airlangga \\ Kampus C Unair, Mulyorejo, Surabaya 60115, Indonesia \\ ${ }^{b}$ Department of Veterinary Reproduction, Faculty of Veterinary Medicine, Brawijaya University \\ Jalan Veteran, Ketawanggede, Lowokwaru, Malang 65145, Indonesia \\ *Corresponding author: imam.mustofa@fkh.unair.ac.id \\ (Received 15-10-2020; Revised 09-02-2021; Accepted 16-02-2021)
}

\begin{abstract}
Kacang goats can be bred through artificial insemination techniques using liquid semen from a superior buck. The study was aimed to determine the quality of Kacang buck semen in chilled storage when green tea extract (GTE) was added to the semen extender. Specifically, 12 ejaculates from three Kacang bucks were diluted in skim milk-egg yolk extender containing 0 $\mathrm{mg}$, $0.05,0.10$, and $0.15 \mathrm{mg}$ of GTE/100 mL. The extended semen was stored at $5^{\circ} \mathrm{C}$, and its quality was evaluated daily for $5 \mathrm{~d}$. Comparatively, semen with $0.10 \mathrm{mg}$ of GTE/100 $\mathrm{mL}$ had the best quality $(p<0.05)$ : it had the highest sperm viability, sperm progressive motility, and sperm intact plasma membrane values, and the lowest malondialdehyde levels and DNA fragmentation percentage. However, as the storage period increased, there was a decrease in sperm viability, sperm motility, and sperm intact plasma membrane values with an increase in malondialdehyde levels and DNA fragmentation $(p<0.05)$. The sperm motility of semen with $0.10 \mathrm{mg}$ of GTE/100 $\mathrm{mL}$ was maintained during $5 \mathrm{~d}$ of chilled storage to meet the qualification for artificial insemination. In contrast, the sperm motility of semen with $0.05 \mathrm{mg}$ and $0.15 \mathrm{mg}$ of GTE/100 mL was maintained for $4 \mathrm{~d}$, whereas that of the control semen was maintained only for $3 \mathrm{~d}$. Thus, the addition $0.10 \mathrm{mg}$ of GTE/100 mL of skim milk-egg yolk extender seems to help maintain the quality of Kacang goat sperm in chilled storage.
\end{abstract}

Keywords: DNA fragmentation; intact plasma membrane; malondialdehyde; sperm motility; poverty reduction

\section{INTRODUCTION}

Kacang goats are small ruminants that are often reared as sources of income to prevent poverty. Given the small size of these goats, they are relatively easy to rear; they do not require a large land area, the cost of investment is relatively low, and there is accessibility to the market. Kacang goats can be bred using artificial insemination (AI) techniques; thus, farmers do not necessarily require their own Kacang bucks. Indeed, superior Kacang bucks owned by breeder groups are selected for their semen, which is used for AI, whereas Kacang bucks not selected for breeding are sold for their goat meat. Either fresh or frozen semen, which is deposited intracervical, can be used for AI; however, frozen Kacang buck semen is not typically available in rural areas (unlike bull semen, which is easily accessed through inseminator services). Therefore, AI of Kacang goats is usually achieved with liquid semen; inseminator trainees are trained to collect and dilute semen for AI of does in estrus.
Currently, there is no minimum standard for the quality of goat semen in chilled storage; hence, we refer to frozen semen standards. The Indonesian National Standard Agency stipulates that the minimum sperm motility in frozen semen be $40 \%$ in 50 million sperm per dose for AI (SNI 4869.3, 2014). With room temperature $\left(24{ }^{\circ} \mathrm{C}\right)$ storage, fresh Kacang buck semen qualifies for AI within $15 \mathrm{~h}$ from the collection (Kusumawati et al., 2017); sperm motility decreases rapidly at room temperature because of lactic acid derived from the metabolism of sperm as they produce energy (Reynolds et al., 2017). Consequently, using fresh semen for AI is challenging, particularly when only a small number of does are being inseminated over a large area. Storage at $5{ }^{\circ} \mathrm{C}$ extends the lifespan of semen for several days before use (Macías et al., 2017); thus, chilling is used to maintain semen quality for transportation and shortterm storage (Di Iorio et al., 2014). The metabolism of sperm slows when it is chilled, which decreases the rate of lactic acid formation and increases sperm lifespan. In an earlier study, we showed that Ettawa buck semen in 
a skim milk extender maintained $43.5 \%$ motility for $4 \mathrm{~d}$ when stored at $5^{\circ} \mathrm{C}$ (Susilowati et al., 2019).

To the best of our knowledge, a protocol for chilled storage of Kacang buck semen has yet to be established. Nevertheless, semen extender is generally considered critical to maintaining the quality of chilled semen. For example, skim milk-egg yolk (SM-EY) extender improves the protection of ram semen during chilled storage (Rahman et al., 2018; Ugur et al., 2020). The presence of antioxidants in extenders provides their protective function; these neutralize reactive oxygen species (ROS) and reduce oxidative stress in sperm (Allai et al., 2018; Kumar et al., 2019). Green tea extract (GTE) is a natural plant antioxidant that contains epigallocatechin-3 gallate (EGCG), which is a potent antioxidant shown to improve the quality of post-thawed sheep sperm (Mehdipour et al., 2016). Thus, we hypothesized that the addition of GTE to SM-EY extenders would extend the lifespan of sperm used for AI. In the present study, we tested this hypothesis with a specific focus on the sperm viability, sperm motility, sperm intact plasma membrane (IPM), malondialdehyde levels, and sperm DNA fragmentation percentage of Kacang buck semen in chilled storage. The study was aimed to determine GTE's effect in SM - EY extenders on the 69 threshold period of sperm viability, sperm motility, sperm IPM, MDA levels, and sperm 70 DNA fragmentations percentage of Kacang buck semen in chilled storage. In general, our results will provide valuable information for the storage and quality maintenance of Kacang buck semen at chilled temperatures.

\section{MATERIALS AND METHODS}

The study was conducted at The Regional Artificial Insemination Center of the Faculty of Veterinary Medicine, Universitas Airlangga, Indonesia. The experimental procedure was approved by The Animal Care and Use Committee, Airlangga University (No. 520/ HRECC.FODM/VII/2019).

\section{Green Tea Extract Preparation}

To prepare the GTE, $1.5 \mathrm{~kg}$ of green tea leaves (Camellia sinensis L. Kuntze) was dried and ground to a particle size of $0.75 \mu \mathrm{m}$, before being soaked in $96 \%$ ethanol for $3 \mathrm{~d}$ in a container covered with aluminum foil. The solution was then filtered using standard cellulose extraction filter paper (Whatman Cellulose Filter Paper, Sigma-Aldrich) with a pore size of $0.5 \mu \mathrm{m}$. The filtrate was rotary-evaporated at $50{ }^{\circ} \mathrm{C}$ and $45 \mathrm{rpm}$ (Greatwall Scientific Industry, Zhengzhou, China) before being further evaporated in an acid chamber (Greatwall Scientific Industry, Zhengzhou, China). Finally, the extract was freeze-dried (Millrock technology, Kingston, New York, USA) and stored at $-20^{\circ} \mathrm{C}$ (Susilowati et al., 2021).

\section{Experimental Animals and Semen Collection}

Three Kacang bucks (2-3 years old) weighing 30$40 \mathrm{~kg}$ were kept in individual pens. They were fed $5 \mathrm{~kg}$ of forage and $3.5 \mathrm{~kg}$ of concentrate $(16 \%-17 \%$ crude protein) daily with drinking water available ad libitum. Semen was collected twice a week using an artificial vagina. A total of 12 ejaculate samples were collected and examined for progressive motility; as all 12 samples had sperm motility $>70 \%$, they were each used as a replicate in the study.

\section{Skim Milk-Egg Yolk Extender}

Skim milk powder (10 g; Merck 115338) was dissolved in $100 \mathrm{~mL}$ of distilled water, heated to $92-95{ }^{\circ} \mathrm{C}$ for $10 \mathrm{~min}$, and then cooled to $37^{\circ} \mathrm{C}$. This solution was added to $5 \mathrm{~mL}$ of egg yolk derived from laboratory chicken eggs to obtain a 100-mL solution; to this, we added penicillin (Meiji Seika Pharma, Tokyo, Japan) $1 \mathrm{IU} / \mathrm{mL}$, and streptomycin (Thermo Fisher Scientific, Singapore) $1 \mathrm{mg} / \mathrm{mL}$ (Susilowati et al., 2021). The solution was then divided into four equal portions to establish treatment groups: the control group (T0, without GTE) and three GTE treatment groups (T1, T2, and T3 with $0.05,0.10$, and $0.15 \mathrm{mg}$ of GTE/100 mL of extender, respectively).

\section{Chilled Semen}

Each ejaculate was divided into four equal volumes and diluted into the four treatment groups (as above) to achieve final sperm levels of 400 million sperm $/ \mathrm{mL}$ (Susilowati et al., 2019). All samples were stored at $5{ }^{\circ} \mathrm{C}$ and evaluated daily for $5 \mathrm{~d}$.

\section{Sperm Quality Assessment}

Sperm viability, progressive motility, plasma membrane integrity, malondialdehyde levels, and DNA fragmentation were evaluated in each treatment group to assess sperm quality (Susilowati et al., 2019).

Viability. To determine sperm viability, samples were dropped on a glass slide, mixed homogenously with eosin (Sigma-Aldrich) and nigrosine (Sigma-Aldrich), smeared, and then dried over a flame; these preparations were examined at $400 \times$ magnification under a light microscope (Olympus BX-53, Shinjuku-ku, Tokyo, Japan). The heads of live sperm appeared brightly transparent as they did not absorb the dye, whereas those of dead sperm absorbed the dye.

Motility. To assess sperm motility, $10 \mu \mathrm{L}$ of the sample was added to $1 \mathrm{~mL}$ of physiologic salt solution before being homogenized, dropped on a glass slide, and then covered. Under $400 \times$ magnification, the number of progressively motile sperm was counted from 100 sperm using a light microscope (Olympus BX-53, Shinjuku-ku, Tokyo, Japan) equipped with Linkam Warming Stages at 37-38 ${ }^{\circ} \mathrm{C}$ (Meyer Instruments, Houston, Texas, USA).

Intact plasma membrane (IPM). To assess the IPM of sperm, a hypoosmotic solution was first produced containing $7.35 \mathrm{~g}$ of sodium citrate $2 \mathrm{H}_{2} \mathrm{O}$ (Sigma-Aldrich) and $13.52 \mathrm{~g}$ of fructose (Sigma-Aldrich) dissolved in $1 \mathrm{~L}$ of distilled water. To $1 \mathrm{~mL}$ of this hypoosmotic solution, 
$0.1 \mathrm{~mL}$ of the sample was added and incubated at $37^{\circ} \mathrm{C}$ for $30 \mathrm{~min}$. The IPM of 100 sperm was assessed under a light microscope (Olympus BX-53, Shinjuku-ku, Tokyo, Japan) at 400× magnification. Sperm with IPMs showed a bent tail, whereas those with a damaged plasma membrane showed a straight tail.

Malondialdehyde levels. The thiobarbituric acid (Sigma-Aldrich) method was used to measure malondialdehyde levels. Along with $100-\mu \mathrm{L}$ samples, malondialdehyde kits containing $0,1,2,3,4,5,6,7$, and $8 \mu \mathrm{g} /$ $\mathrm{mL}$ were respectively added to $550 \mu \mathrm{L}$ of distilled water with $100 \mu \mathrm{L}$ of $20 \%$ trichloroacetic acid. These mixtures were homogenized for $30 \mathrm{~s}$ before $250 \mu \mathrm{L}$ of $1 \mathrm{~N} \mathrm{HCl}$ was added and homogenized, and then $100 \mu \mathrm{L}$ of $1 \%$ sodium thiobarbiturate was added and homogenized. The final mixture was centrifuged at $500 \mathrm{rpm}$ for $10 \mathrm{~min}$, and then the supernatant was incubated in a water bath at $100{ }^{\circ} \mathrm{C}$ for $30 \mathrm{~min}$ before being left at room temperature. The color absorption was read in a spectrophotometer (Thermo Fisher Scientific) at a wavelength of $533 \mathrm{~nm}$, and malondialdehyde levels $(\mathrm{ng} / \mathrm{mL})$ were obtained on the basis of the extrapolation of sample absorbance values against the standard malondialdehyde curve.

DNA fragmentation. DNA fragmentation of sperm was assessed using acridine orange staining. First, the sample was dropped on a glass slide, smeared, air dried, and fixed in $96 \%$ ethanol (1:1) for $30 \mathrm{~min}$ at $4{ }^{\circ} \mathrm{C}$. After air drying at room temperature, the slide was hydrolyzed in $0.1 \mathrm{~N} \mathrm{HCl}$ for $5 \mathrm{~min}$ at $4^{\circ} \mathrm{C}$, rinsed three times with distilled water, and then stained with $0.05 \%$ toluidine blue (Sigma-Aldrich) for $10 \mathrm{~min}$. Afterward, the slide was washed in distilled water, dehydrated using t-butanol (Sigma-Aldrich), and cleaned twice with xylol (Sigma-Aldrich). The DNA fragmentation of 100 sperm was examined under a light microscope (Olympus BX53, Shinjuku-ku, Tokyo, Japan) at 400× magnification. Yellow-colored sperm heads indicated intact DNA, whereas green-colored sperm heads indicated fragmented DNA (Dwinofanto et al., 2018).

\section{Data Analysis}

Sperm quality indicator (viability, motility, IPM, malondialdehyde levels, and DNA fragmentation) values among treatment groups and storage times were analyzed using ANOVA followed by Tukey's honestly significant difference test. The statistical analysis was conducted to a $95 \%$ level of significance using Statistical Product and Service Solutions (SPSS) Version 23.

\section{RESULTS}

From $1.5 \mathrm{~kg}$ of dried green tea leaves, $1.2 \mathrm{~kg}$ of powder $(0.75-\mu \mathrm{m}$ particle size) was produced. Extraction of the powder with ethanol yielded a thick GTE (205 g), which reduced in weight after freezedrying (129 g).

The characteristics of the goat ejaculate used in this study were as follows: yellowish-white in color with a specific odor, thick consistency, and $\mathrm{pH}$ of approxi- mately 7. The average volume and levels of ejaculate were $2.33 \pm 0.37 \mathrm{~mL}$ and $3679.15 \pm 320.92$ sperm $/ \mathrm{mL}$, respectively. The viability, progressive motility, and IPM of the ejaculate were $91.30 \pm 1.75 \%, 88.05 \pm 2.33 \%$, and $84.26 \pm 2.04 \%$, respectively (Table 1 ).

\section{Quality of Chilled Semen Based on the Addition of Green Tea Extract}

Compared with fresh ejaculate, there was a substantial decline in sperm viability and progressive motility in the control group (T0) at $24 \mathrm{~h}$ after samples were in chill-stored (see Day 1 in Table 2). With $0.10 \mathrm{mg}$ of GTE/100 mL of SM-EY extender, this decline was reduced (see Day 1 for T2 in Table 2). Higher levels of GTE seemed to improve semen quality to a certain extent, after which semen quality decreased (Table 2). Specifically, the T2 group ( $0.1 \mathrm{mg}$ of GTE/100 mL of extender) had the best semen quality $(p<0.05)$, as it had the highest sperm viability, motility (Table 2), and IPM percentages, as well as the lowest malondialdehyde levels (Table 3) and DNA fragmentation percentage (Table 4). Indeed, the T3 group ( $0.15 \mathrm{mg}$ of GTE/100 $\mathrm{mL}$ of extender) had significantly lower semen quality $(p<0.05)$ than the T2 group.

\section{Quality of Chilled Semen Based on Storage Time}

Semen quality decreased significantly as storage time increased $(\mathrm{p}<0.05)$; sperm viability, sperm motility (Table 2), and sperm IPM levels decreased over time, whereas malondialdehyde levels (Table 3) and DNA fragmentation (Table 4) increased. The sperm motility threshold (40\%) period was $3 \mathrm{~d}$ in T0, $4 \mathrm{~d}$ in $\mathrm{T} 1$ and T3, and at least $5 \mathrm{~d}$ in $\mathrm{T} 2$.

\section{DISCUSSION}

Sperm motility is a critical performance indicator of semen quality as a requirement for AI. Although there is no minimum standard for the sperm motility of chilled goat semen, frozen semen standards suggest that motility should be at least $70 \%$ to qualify for AI (SNI $4869.3,2014)$. The freshly ejaculated Kacang goat semen collected in the present study had sperm motility of $88.05 \pm 2.33 \%$, making it suitable for AI.

The Kacang buck semen used in the current study was diluted in SM-EY. Skim milk contains sulfhydryl groups, nonenzymatic antioxidants, $\beta$-lactoglobulin, and phosphocaseinate, which all help to prevent the harmful effects of metabolism by-products. In addition, casein micelles effectively preserve plasma mem-

Table 1. The variables of fresh Kacang goat semen

\begin{tabular}{lc}
\hline Variables & Values \\
\hline Sperm volume (mL) & $2.33 \pm 0.37$ \\
Sperm concentration (million/mL) & $3,679.15 \pm 320.92$ \\
Sperm viability (\%) & $91.30 \pm 1.75$ \\
Sperm progressive motility (\%) & $88.05 \pm 2.33$ \\
Sperm intact plasma membrane (\%) & $85.26 \pm 2.04$ \\
\hline
\end{tabular}


Table 2. Sperm viability and sperm motility of Kacang buck semen treated using green tea extract in skim milk-egg yolk (SM-EY) extender and stored at $5{ }^{\circ} \mathrm{C}$ for 5 days

\begin{tabular}{|c|c|c|c|c|c|c|}
\hline \multirow{2}{*}{ Variables } & \multicolumn{6}{|c|}{ Storage times } \\
\hline & Day 0 & Day 1 & Day 2 & Day 3 & Day 4 & Day 5 \\
\hline \multicolumn{7}{|c|}{ Sperm viability } \\
\hline T0 & $77.15 \pm 0.82^{\mathrm{Ad}}$ & $75.15 \pm 0.22^{\mathrm{Bd}}$ & $66.57 \pm 0.24^{\mathrm{Cd}}$ & $53.17 \pm 0.12^{\mathrm{Dd}}$ & $39.35 \pm 0.23^{\mathrm{Ec}}$ & $27.85 \pm 0.58^{\mathrm{Fc}}$ \\
\hline $\mathrm{T} 1$ & $84.65 \pm 0.61^{\mathrm{Ab}}$ & $82.35 \pm 0.24^{\mathrm{Bb}}$ & $72.65 \pm 0.24^{\mathrm{cb}}$ & $59.56 \pm 0.32^{\mathrm{Db}}$ & $41.31 \pm 0.58^{\mathrm{Eb}}$ & $36.17 \pm 0.38^{\mathrm{Fb}}$ \\
\hline $\mathrm{T} 2$ & $90.15 \pm 0.42^{\mathrm{Aa}}$ & $88.64 \pm 0.24^{\mathrm{Ba}}$ & $79.35 \pm 0.25^{\mathrm{Ca}}$ & $66.19 \pm 0.18^{\mathrm{Da}}$ & $50.08 \pm 0.15^{\mathrm{Ea}}$ & $43.10 \pm 0.27^{\mathrm{Fa}}$ \\
\hline T3 & $81.94 \pm 0.81^{\mathrm{Ac}}$ & $79.56 \pm 0.43^{\mathrm{Bc}}$ & $67.57 \pm 0.41^{\mathrm{Cc}}$ & $55.35 \pm 0.17^{\mathrm{Dc}}$ & $39.54 \pm 0.27^{\text {Ес }}$ & $28.50 \pm 0.24^{\mathrm{Fc}}$ \\
\hline \multicolumn{7}{|c|}{ Sperm motility } \\
\hline T0 & $76.06 \pm 0.63^{\mathrm{Ad}}$ & $73.35 \pm 0.25^{\mathrm{Bd}}$ & $65.65 \pm 0.37^{\mathrm{Cc}}$ & $51.25 \pm 0.51^{\mathrm{Dd}}$ & $38.54 \pm 0.18^{\mathrm{Ec}}$ & $25.55 \pm 0.32^{\mathrm{Fd}}$ \\
\hline $\mathrm{T} 1$ & $83.48 \pm 0.69^{\mathrm{Ab}}$ & $80.44 \pm 0.28^{\mathrm{Bb}}$ & $70.50 \pm 0.34^{\mathrm{Cb}}$ & $58.15 \pm 0.33^{\mathrm{Db}}$ & $40.05 \pm 0.31^{\mathrm{Eb}}$ & $31.60 \pm 0.39^{\mathrm{Fb}}$ \\
\hline $\mathrm{T} 2$ & $87.55 \pm 0.73^{\mathrm{Aa}}$ & $85.30 \pm 0.35^{\mathrm{Ba}}$ & $77.45 \pm 0.22^{\mathrm{Ca}}$ & $62.28 \pm 0.37^{\mathrm{Da}}$ & $48.25 \pm 0.34^{\mathrm{Ea}}$ & $39.75 \pm 0.22^{\mathrm{Fa}}$ \\
\hline T3 & $79.30 \pm 1.09^{\mathrm{Ac}}$ & $74.25 \pm 0.23^{\mathrm{Bc}}$ & $66.35 \pm 0.28^{\mathrm{Cc}}$ & $54.28 \pm 0.30^{\mathrm{Dc}}$ & $38.35 \pm 0.28^{\mathrm{Ec}}$ & $27.45 \pm 0.28^{\mathrm{Fc}}$ \\
\hline
\end{tabular}

Note: ${ }^{\mathrm{A}-\mathrm{F}}$ Means in the same row with different superscripts differ significantly $(\mathrm{p}<0.05)$. $^{\mathrm{a}-\mathrm{d}}$ Means in the same column with different superscripts differ significantly $(\mathrm{p}<0.05)$. Day $0=$ immediately after dilution (before storage); T0=SM-EY without GTE; T1, T2, and T3= SM-EY extender with the addition of $0.05,0.10$, and $0.15 \mathrm{mg}$ of GTE/100 $\mathrm{mL}$ of extender, respectively. Values in bold indicate the best quality parameters of semen.

Table 3. Sperm intact plasma membrane (IPM) and malondialdehyde levels of Kacang buck semen treated using green tea extract in skim milk-egg yolk (SM-EY) extender and stored at $5{ }^{\circ} \mathrm{C}$ for 5 days

\begin{tabular}{|c|c|c|c|c|c|c|}
\hline \multirow{2}{*}{ Variables } & \multicolumn{6}{|c|}{ Storage times } \\
\hline & Day 0 & Day 1 & Day 2 & Day 3 & Day 4 & Day 5 \\
\hline \multicolumn{7}{|c|}{ Sperm IPM } \\
\hline T0 & $57.69 \pm 1.00^{\mathrm{Ad}}$ & $50.18 \pm 0.42^{\mathrm{Bc}}$ & $45.20 \pm 0.19^{\mathrm{Cd}}$ & $38.15 \pm 0.29^{\mathrm{Dc}}$ & $30.54 \pm 0.10^{\mathrm{Ec}}$ & $25.45 \pm 0.58^{\mathrm{Fd}}$ \\
\hline $\mathrm{T} 1$ & $64.27 \pm 0.94^{\mathrm{Ab}}$ & $60.10 \pm 0.21^{\mathrm{Bb}}$ & $50.25 \pm 0.28^{\mathrm{Cb}}$ & $39.45 \pm 0.14^{\mathrm{Db}}$ & $38.71 \pm 0.22^{\mathrm{Eb}}$ & $28.54 \pm 0.27^{\mathrm{Fb}}$ \\
\hline $\mathrm{T} 2$ & $69.71 \pm 0.92^{\mathrm{Aa}}$ & $65.35 \pm 0.09^{\mathrm{Ba}}$ & $54.10 \pm 0.28^{\mathrm{Ca}}$ & $50.05 \pm 0.21^{\mathrm{Da}}$ & $41.55 \pm 0.11^{\mathrm{Ea}}$ & $36.06 \pm 0.09^{\mathrm{Fa}}$ \\
\hline T3 & $59.85 \pm 0.73^{\mathrm{Ac}}$ & $49.60 \pm 0.14^{\mathrm{Bd}}$ & $47.15 \pm 0.07^{\mathrm{Cc}}$ & $37.90 \pm 0.09^{\mathrm{Dc}}$ & $30.50 \pm 0.52^{\mathrm{Ec}}$ & $27.02 \pm 0.11^{\mathrm{Fc}}$ \\
\hline \multicolumn{7}{|c|}{ Sperm malondialdehyde levels } \\
\hline T0 & $2136.93 \pm 11.13^{\text {Fа }}$ & $2235.16 \pm 0.19^{\mathrm{Ea}}$ & $2512.51 \pm 0.10^{\mathrm{Da}}$ & $2609.65 \pm 0.16^{\mathrm{Ca}}$ & $2846.86 \pm 0.26^{\mathrm{Ba}}$ & $3126.83 \pm 0.10^{\text {Aa }}$ \\
\hline $\mathrm{T} 1$ & $1790.17 \pm 41.15^{\mathrm{Fc}}$ & $1875.20 \pm 0.13^{\mathrm{Ec}}$ & $2092.36 \pm 0.13^{\mathrm{Dc}}$ & $2215.73 \pm 0.12^{\mathrm{Cc}}$ & $2532.42 \pm 0.10^{\mathrm{Bc}}$ & $2831.34 \pm 0.21^{\mathrm{Ac}}$ \\
\hline $\mathrm{T} 2$ & $1379.53 \pm 21.34^{\mathrm{Fd}}$ & $1586.33 \pm 0.11^{\mathrm{Ed}}$ & $1776.19 \pm 0.12^{\mathrm{Dd}}$ & $1825.35 \pm 0.13^{\mathrm{Cd}}$ & $1976.54 \pm 0.13^{\text {Bd }}$ & $2196.54 \pm 0.10^{\mathrm{Ac}}$ \\
\hline T3 & $1834.15 \pm 361.19^{\mathrm{Fb}}$ & $2198.37 \pm 0.17^{\mathrm{Eb}}$ & $2226.32 \pm 0.13^{\mathrm{Db}}$ & $2485.26 \pm 0.17^{\mathrm{Cb}}$ & $2705.59 \pm 0.10^{\mathrm{Bb}}$ & $2985.50 \pm 0.12^{\mathrm{Ab}}$ \\
\hline
\end{tabular}

Note: ${ }^{A-F}$ Means in the same row with different superscripts differ significantly $(p<0.05)$. $^{a-d}$ Means in the same column with different superscripts differ significantly $(\mathrm{p}<0.05)$. Day $0=$ immediately after dilution (before storage); $\mathrm{T} 0=\mathrm{SM}-\mathrm{EY}$ without $\mathrm{GTE} ; \mathrm{T} 1$, $\mathrm{T} 2$, and $\mathrm{T} 3=\mathrm{SM}-\mathrm{EY}$ extender with the addition of $0.05,0.10$, and $0.15 \mathrm{mg}$ of GTE/100 $\mathrm{mL}$ of extender, respectively. Values in bold indicate the best quality parameters of semen.

Table 4. Sperm DNA fragmentation (\%) of Kacang buck semen treated using green tea extract in skim milk-egg yolk (SM-EY) extender and stored at $5{ }^{\circ} \mathrm{C}$ for 5 days

\begin{tabular}{|c|c|c|c|c|c|c|}
\hline \multirow{2}{*}{ Treatments } & \multicolumn{6}{|c|}{ Storage times } \\
\hline & Day 0 & Day 1 & Day 2 & Day 3 & Day 4 & Day 5 \\
\hline T0 & $4.23 \pm 0.08^{\mathrm{Fa}}$ & $5.25 \pm 0.22^{\mathrm{Ca}}$ & $5.45 \pm 0.14^{\mathrm{Ca}}$ & $6.75 \pm 0.14^{\mathrm{Ba}}$ & $6.85 \pm 0.24^{\mathrm{Ba}}$ & $7.60 \pm 0.15^{\mathrm{Aa}}$ \\
\hline $\mathrm{T} 1$ & $3.84 \pm 0.15^{\mathrm{Fb}}$ & $4.75 \pm 0.22^{\mathrm{Db}}$ & $5.30 \pm 0.14^{\mathrm{Cb}}$ & $6.10 \pm 0.42^{\mathrm{Bb}}$ & $6.40 \pm 0.21^{\mathrm{Bb}}$ & $7.40 \pm 0.23^{\mathrm{Aa}}$ \\
\hline $\mathrm{T} 2$ & $2.09 \pm 0.17^{\mathrm{Fc}}$ & $2.40 \pm 0.18^{\mathrm{Ed}}$ & $2.77 \pm 0.18^{\mathrm{Dd}}$ & $3.65 \pm 0.16^{\mathrm{Cd}}$ & $3.90 \pm 0.09^{\mathrm{Bd}}$ & $4.75 \pm 0.18^{\mathrm{Ac}}$ \\
\hline $\mathrm{T} 3$ & $3.67 \pm 0.20^{\mathrm{Fb}}$ & $4.20 \pm 0.12^{\mathrm{Dc}}$ & $4.42 \pm 0.17^{\mathrm{cc}}$ & $5.25 \pm 0.07^{\mathrm{cc}}$ & $5.50 \pm 0.11^{\mathrm{Bc}}$ & $5.80 \pm 0.16^{\mathrm{Ab}}$ \\
\hline
\end{tabular}

Note: ${ }^{A-F}$ Means in the same row with different superscripts differ significantly $(p<0.05)$. ${ }^{a-d}$ Means in the same column with different superscripts differ significantly $(\mathrm{p}<0.05)$. Day $0=$ immediately after dilution (before storage); $\mathrm{T} 0=\mathrm{SM}-\mathrm{EY}$ without $\mathrm{GTE} ; \mathrm{T} 1$, $\mathrm{T} 2$, and $\mathrm{T} 3=\mathrm{SM}-\mathrm{EY}$ extender with the addition of $0.05,0.10$, and $0.15 \mathrm{mg}$ of GTE/100 mL of extender, respectively. Values in bold indicate the best quality parameters of semen.

brane stability and protect sperm from the oxidative stress caused by lipid peroxidation (Fadl et al., 2020). Furthermore, egg yolk is rich in cholesterol, which improves the quality of frozen semen (Anzar et al., 2019); it helps decrease mitochondrial, and plasma membrane deterioration and thereby inhibits DNA damage (Ezz et al., 2017).
We found that the presence of GTE in the SM-EY extender reduced the dramatic decline in semen quality that occurred during chilled storage. High sperm quality requires a balance of ROS-mediated mitochondrial metabolism and endogenous antioxidants in semen plasma (Leite et al., 2010). ROS plays a vital role in regulating sperm functions (Wagner et al., 2018), such as 
maturation, hyperactivation, sperm-oocyte fusion, and the acrosome reaction (Sanocka \& Kurpisz, 2004). At low levels, ROS also functions in tyrosine phosphorylation, sterol oxidation, and cholesterol efflux in the process of capacitation and fertilization (Takeshima et al., 2018). However, the overproduction of ROS causes oxidative stress, damages sperm DNA, and ultimately reduces fertility (Thompson et al., 2014).

Aerobic respiration in cells produces ROS as a by-product. High levels of ROS restrict the use of ATP in mitochondria, which in turn reduces sperm viability, motility, and membrane integrity (Sanocka \& Kurpisz, 2004). Oxidative phosphorylation is an electron transport chain in mitochondria in which nicotinamide adenine dinucleotide acts as an electron donor and oxygen acts as an electron acceptor. This process is the reduction and oxidation reaction involved in ATP synthesis, which provides the energy needed for sperm motility (Wagner et al., 2018). High ROS levels disrupt electron flow along this electron transport chain, leading to electron leakage in the mitochondria and a consequent negative effect on sperm motility and DNA integrity (Takeshima et al., 2018).

In the present study, the antioxidants derived from the T1 group seem to have been insufficient to offset excess ROS production. Oxidative stress occurs when there is an imbalance in oxidation and reduction reactions, which results in an increase in oxidants or molecules that can readily accept electrons compared with other molecules. Lipids in membranes and carbohydrates in nucleic acids can easily accept unpaired electrons (Wagner et al., 2018). Sperm have endogenous antioxidants, such as glutathione peroxidase, catalase, and superoxide dismutase, and the sperm membrane consists of polyunsaturated fatty acids, which are sensitive to oxidation. When ROS levels are higher than those of the endogenous antioxidants, as would likely be the case with the T1 GTE treatment, lipid peroxidation will occur in the sperm membrane. Lipid peroxidation causes the loss of membrane integrity with increased permeability, which reduces sperm motility and increases DNA damage (Takeda et al., 2015). It also generates toxic lipid aldehyde species, including malondialdehyde; thus, malondialdehyde levels reflect the extent to which cells are attacked by free radicals (Wen et al., 2019) and incur sperm plasma membrane damage. As shown in the present study, an increase in malondialdehyde levels is followed by a decrease in sperm IPM. Sperm plasma membranes protect the organelles from mechanical damage and act as filters to exchange intracellular and extracellular substances; therefore, plasma membrane integrity is vital for sperm success and affects motility, viability, and DNA integrity (Leite et al., 2010), including sperm chromatin structural damage (Manente et al., 2015). The observed changes in DNA fragmentation in the current work were consistent with the changes in malondialdehyde levels and inversely related to sperm IPMs.

We speculate that the following physiological mechanism is responsible for the positive effect of GTE in the T2 group on Kacang goat semen quality. First,
GTE passed through the cell membrane and protected DNA from free radical damage. The antioxidant action of GTE could have lowered the acid phosphatase enzyme levels, which are an indicator of cellular death or damage (El-Battawy, 2019). Additionally, the EGCG from GTE likely controlled ROS production by regulating catalase, superoxide dismutase 1 , superoxide dismutase 2, and glutathione peroxidase levels (Zhang et al., 2020). Furthermore, GTE may have improved sperm capacitation, tyrosine phosphorylation, and cholesterol efflux via the estrogen receptor pathway (MartinHidalgo et al., 2019). Although the T2 treatment most improved goat semen quality, lower semen quality was observed following a higher treatment of GTE in the T3 group. The EGCG contained in GTE is a potent antioxidant; overly high exposure to antioxidants (reductants) creates an antioxidant paradox that can negatively affect cells and male fertility (Majzoub \& Agarwal, 2018; Majzoub et al., 2018). Additionally, the higher dose of antioxidants in T3 could have reduced ROS levels to the extent that the physiological function of sperm was affected. In both cases, the T3 GTE treatment would have lowered sperm quality.

As storage time increases, the percentage of live sperm is known to decrease (Hahn et al., 2019). In addition, temperature fundamentally affects semen motility. Skim milk-based extenders can preserve goat semen for 5 or $17 \mathrm{~h}$ at room or chilled $\left(4^{\circ} \mathrm{C}\right)$ temperatures, respectively (Ferdinand et al., 2012); indeed, sperm stored at 4 ${ }^{\circ} \mathrm{C}$ survive longer than sperm stored at $23{ }^{\circ} \mathrm{C}$ (Wusiman et al., 2012). The decrease in sperm quality over time is likely due to ROS accumulation, which leads to the loss of membrane selectivity and permeability. Superoxide dismutase and catalase are essential components of the antioxidant system in seminal plasma as they can antagonize and block free radicals; however, their levels become insufficient when ROS is overproduced because of cooling and extended storage (Wen et al., 2019). An extender can increase the lifespan of sperm, but its effects are lessened with storage time, which is directly proportional to increases in ROS levels. As shown in the present study, extended storage increases ROS accumulation in the media, which consequently decreases sperm viability, motility, and IPM, while increasing malondialdehyde levels and DNA fragmentation. Nevertheless, despite the negative effect of storage time on semen quality, the T0, T1, and T3 groups studied here still met the requirements for AI (i.e., $\geq 40 \%$ progressive motility) until the third day of storage. Importantly, the T2 treatment met the AI requirement until the fifth day. These results show an improvement compared with refrigerator-preserved ram semen, which was acceptable for AI for approximately $48 \mathrm{~h}$ in skim milk extender (Rahman et al., 2018).

DNA quality plays a vital role in embryo development; sperm DNA fragmentation due to oxidative stress can result in pregnancy failure (Takeda et al., 2015). In fact, high sperm DNA fragmentation levels are negatively correlated with fertilization rates (Manente et al., 2015). In our previous study, sperm DNA fragmentation $<7 \%$ resulted in a satisfactory pregnancy rate (Susilowati 
et al., 2020). In the present study, 7\% sperm DNA fragmentation was reached at $4 \mathrm{~d}$ of chilled storage in the T0 and $\mathrm{T} 1$ groups and $5 \mathrm{~d}$ in $\mathrm{T} 2$ and $\mathrm{T} 3$.

\section{CONCLUSION}

It can be concluded that the addition of $0.10 \mathrm{mg}$ of GTE/100 mL of SM-EY extender maintains the highest quality of Kacang goat sperm (based on the highest sperm viability, motility, and IPM, with the lowest malondialdehyde levels and DNA fragmentation percentage) when it is chill-stored for $5 \mathrm{~d}$. This additive method could therefore be used with chilled semen storage in the field to improve AI success in goats.

\section{CONFLICT OF INTEREST}

We declare no conflicts of interest with any financial, personal, or other relationships with other people or organizations related to the manuscript material.

\section{ACKNOWLEDGEMENT}

This research was supported by the Universitas Airlangga (contract number: 360/UN3.14/PT/2020). The authors thank Dr. Trilas Sardjito (DMV., M.Kes), the Chairman of the Regional Insemination Center, Faculty of Veterinary Medicine Universitas Airlangga, as well as Subchan Aziz and Agus Purwanto for technical support. The authors also thank the Center for Journal Development and Scientific Publication of Airlangga University and Enago for English language editing and proofreading of the manuscript.

\section{REFERENCES}

Allai, L., A. Benmoula, M. M. Marciane da Silva, B. Nasser, \& B. El Amiri. 2018. Supplementation of ram semen extender to improve seminal quality and fertility rate. Anim. Reprod. Sci. 192:6-17. https://doi.org/10.1016/j. anireprosci.2018.03.019

Anzar, M., K. Rajapaksha, \& L. Boswall. 2019. Egg yolk-free cryopreservation of bull semen. PLOS ONE 14:e0223977. https://doi.org/10.1371/journal.pone.0223977

Di Iorio, M., A. Manchisi, M. Rocco, P. Chrenek, \& N. Iaffaldano. 2014. Comparison of different extenders on the preservability of rabbit semen stored at $5^{\circ} \mathrm{C}$ for 72 hours. Ital. J. Anim. Sci. 13:3444. https://doi.org/10.4081/ ijas.2014.3444

Dwinofanto, H., R. Rimayanti, I. Mustofa, S. Susilowati, \& T. Hernawati. 2018. The effect of duration of preservation on the quality, MDA level, and DNA damage of post-thawed Bali cattle bull sperm. Iraqi J. Vet. Sci. 32:249-252. https:// doi.org/10.33899/ijvs.2019.153857

El-Battawy, K. A. 2019. Preservation of goat semen at $5^{\circ} \mathrm{C}$ with emphasis on its freezability and the impact of melatonin. Int. J. Vet. Sci. Res. 5:035-038. https://doi.org/10.17352/ ijvsr.000039

Ezz, M. A., A. E. Montasser, M. Hussein, A. Eldesouky, M. Badr, A. E. Hegab, A. Balboula, \& S. M. Zaabel. 2017. The effect of cholesterol loaded cyclodextrins on post-thawing quality of buffalo semen in relation to sperm DNA damage and ultrastructure. Reprod. Biol. 17:42-50. https://doi. org/10.1016/j.repbio.2016.12.001

Fadl, A. M., A. M. Ghallab, \& M. M. Abou-Ahmed. 2020.
Comparison between Tris-buffer and INRA-82 extenders on the quality of chilled rabbit spermatozoa. World Rabbit Sci. 28:13-18. https://doi.org/10.4995/wrs.2020.12287

Ferdinand, N., T. T. Thomas, K. Augustave, D. F. Henry, T. Fernand, \& P. T. Etienne. 2012. Effects of goat age, storage duration, storage temperature and diluent on fresh West African Dwarf goat semen. J. Reprod. Infertil. 3:58-66. https://doi.org/10.5829/idosi.jri.2012.3.3.66216

Hahn, K., K. Failing, \& A. Wehrend. 2019. Effect of temperature and time after collection on goat semen quality. BMC Vet. Res. 15:355. https://doi.org/10.1186/s12917-019-2135-y

Kumar, A., J. K. Prasad, N. Srivastava, \& S. K. Ghosh. 2019. Strategies to minimize various stress-related freeze-thaw damages during conventional cryopreservation of mammalian spermatozoa. Biopreserv. Biobank. 17:603-612. https://doi.org/10.1089/bio.2019.0037

Kusumawati, E. D., K. N. Utomo, A. T. N. Krisnaningsih, \& S. Rahadi. 2017. Kualitas semen kambing Kacang dengan lama simpan yang berbeda pada suhu ruang menggunakan pengencer tris aminomethan kuning telur. JITRO 4:4251. https://doi.org/10.33772/jitro.v4i3

Leite, T. G., V. R. de Vale Filhoa, R. P. de Arrudab, A. F. C. de Andradeb, L.L. Emericka, F. G. Zaffalonb, J. A. M. Martinsa, \& V. J. Andrade. 2010. Effects of extender and equilibration periodon post-thaw motility and membrane integrity of cryopreserved Gyr bull semen evaluated by CASA and flow cytometry. Anim. Reprod. Sci. 120:31-38. https://doi.org/10.1016/j.anireprosci.2010.04.005

Macías, A., L. M. Ferrer, J. J. Ramos, I. Lidón, R. Rebollar, D. Lacasta, \& M. T. Tejedor. 2017. Technical Note: A new device for cervical insemination of sheep - design and field test. J. Anim. Sci. 95:5263-5269. https://doi.org/10.2527/ jas2017.1951

Majzoub, A. \& A. Agarwal. 2018. Systematic review of antioxidant types and doses in male infertility: benefits on semen parameters, advanced sperm function, assisted reproduction and live-birth rate. Arab J. Urol. 16:113-124. https:// doi.org/10.1016/j.aju.2017.11.013

Majzoub, A., A. Agarwal, \& S. C. Esteves. 2017. Antioxidants for elevated sperm DNA fragmentation: a mini review. Transl. Androl. Urol. 6 (Suppl 4):S649-S653. https://doi. org/10.21037/tau.2017.07.09

Manente, L., S. Pecoraro, E. Picillo, U. Gargiulo, P. Gargiulo, A. De Luca, \& L. Politano. 2015. Molecular evidence of apoptotic pathway activation in semen samples with high DNA fragmentation. In vivo 29: 289-294.

Martin-Hidalgo, D., M. J. Bragado, A. R. Batista, P. F. Oliveira, \& M. G. Alves. 2019. Antioxidants and male fertility: From molecular studies to clinical evidence. Antioxidants 8: 89: 1-21. https://doi.org/10.3390/antiox8040089

Mehdipour, M., H. D. Kia, A. Najafi, H.V. Dodaran, \& O. García-Álvarez. 2016. Effect of green tea (Camellia sinensis) extract and pre-freezing equilibration periodon the postthawing quality of ram semen cryopreserved in a soybean lecithin based extender. Cryobiology 73:297-303. https:// doi.org/10.1016/j.cryobiol.2016.10.008

Rahman, M. S., M. R. Gofur, M. M. Rahman, F. Y. Bari, \& N. S. Juyena. 2018. Effect of skim milk and tris-citrate extenders to preserve the semen of indigenous ram of Bangladesh. AJOB 5:1-11. https://doi.org/10.9734/AJOB/2018/39448

Reynolds, S., N. F. B. Ismail, S. J. Calvert, A. A. Pacey, \& M. N. J. Paley. 2017. Evidence for rapid oxidative phosphorylation and lactate fermentation in motile human sperm by hyperpolarized 13C magnetic resonance spectroscopy. Sci. Rep. 7:4322. https://doi.org/10.1038/s41598-017-04146-1

Sanocka, D. \& M. Kurpisz. 2004. Reactive oxygen species and sperm cells. Reprod. Biol. Endocrinol. 2: 1-7. https://doi. org/10.1186/1477-7827-2-12

Setiawan, F. \& E. D. Kusumawati. 2017. The quality of fresh 
semen Goat at $5^{\circ} \mathrm{C}$ storage with and without an extender. J. Anim. Sci. 95:77-85. https://doi.org/10.21067/jsp.v5i2.3157

Standar Nasional Indonesia (SNI) 4869.3. 2014. Semen beku - Bagian 3 : Kambing dan domba. Badan Standardisasi Nasional Indonesia. Retrieved from: http://bibit.ditjenpkh. pertanian.go.id/sites/default/files/SNI\%204869.3-2014\%20 Semen $\% 20$ beku $\% 2$ C\%20Bagian $\% 203 \% 20$ Kambing $\% 20$ dan $\% 20$ domba $\% 20 \% 20 \% 2001$.pdf [June 23, 2020].

Susilowati, S., I. N. Triana, T. Sardjito, T. W. Suprayogi, W. Wurlina, \& I. Mustofa. 2020. Effect of Simmental bull seminal plasma protein in egg yolk-citrate extender on Kacang buck semen fertility. Cryobiology 97:20-27. https://doi. org/10.1016/j.cryobiol.2020.10.013

Susilowati, S., I. N. Triana, W. Wurlina, A. Arimbi, P. Srianto, \& I. Mustofa. 2019. Supplementation of L-arginine in skim milk extender maintains goat semen quality in chilled temperature for five days. Vet. World. 12:1784-1789. https:// doi.org/10.14202/vetworld.2019.1784-1789

Susilowati, S., T. Sardjito, I. Mustofa, O. S. Widodo, \& R. Kurnijasanti. 2021. Effect of green tea extract in extender of Simmental bull semen on pregnancy rate of recipients. AJAS. Anim. Biosci. 34:198-204. https://doi.org/10.5713/ ajas. 20.0025

Takeda, K., K. Uchiyama, M. Kinukawa, T. Tagami, M. Kaneda, \& S. Watanabe. 2015. Evaluation of sperm DNA damage in bulls by TUNEL assay as a parameter of semen quality. J. Reprod. Dev. 61:185-190. https://doi.org/10.1262/ jrd.2014-140

Takeshima, T., S. Kuroda, \& Y. Yumura. 2018. Chapter 6: Reactive Oxygen Species and Sperm Cells. https://doi. org/10.5772/intechopen.73037
Thompson, A., A. Agarwal, \& S. S. Du Plessis. 2014. The Physiological Role of Reactive Oxygen Species in Sperm Function: A review. In: Parekattil, S. J. \& A. Agarwal (Eds). Antioxidants in Male Infertility: A Guide for Clinicians and Researchers. Springer Science+Business Media, New York. https://doi.org/10.1007/978-1-4614-9158-3_4

Ugur, M. R., T. Dinh, M. Hitit, M., A. Kaya, E. Topper, B. Didion, \& E. Memili. 2020. Amino acids of seminal plasma associated with freezability of bull sperm. Front. Cell Dev. Biol. 7: 347. https://doi.org/10.3389/fcell.2019.00347

Wagner, H., J. W. Cheng, \& E. Y. Ko. 2018. Role of reactive oxygen species in male infertility: An updated review of the literature. Arab J. Urol. 16:35-43. https://doi.org/10.1016/j. aju.2017.11.001

Wen, F., Y. Li, T. Feng, Y. Du, F. Ren, L. Zhang, N. Han, S. Ma F. Li, P. Wang, \& J. Hu. 2019. Grape seed procyanidin extract (GSPE) improves goat semen quality when preserved at $4^{\circ} \mathrm{C}$. Animals 9:1-11. https://doi.org/10.3390/ani9100810

Wusiman, A. Y. P. W., K. Ren, G. B. Zhou, X. W. Fu, L. Suo, Z. Q. Fan, L. Wang, \& S. E. Zhu. 2012. Semen storage at 23,4 or $-196^{\circ} \mathrm{C}$ and its application to artificial insemination in Small-tail Han Sheep. AJAVA 7:299-308. https://doi. org/10.3923/ajava.2012.299.308

Zhang, Y., H. Lin, C. Liu, J. Huang, \& Z. Liu. 2020. A review for physiological activities of EGCG and the role in improving fertility in humans/mammals. Biomed. Pharmacother. 127:1-10 (110186). https://doi.org/10.1016/j. biopha.2020.110186 